\title{
Deoxyribonucleic Acid Base Composition and Numerical Taxonomy of Yeasts in the Genus Trichosporon
}

\author{
By P. F. DUPONT AND L. R. HEDRICK \\ Biology Department, Illinois Institute of Technology, Chicago, Illinois 60616, U.S.A.
}

(Accepted for publication 15 April 197I)

\begin{abstract}
SUMMARY
Of the 49 strains of Trichosporon yeasts studied, 40 were retained in the genus and assigned to Io species. The others were transferred to the genera Candida and Endomycopsis. The DNA base composition was determined for a representative of each Trichosporon species. On the basis of guanine and cytosine content ( $\% \mathrm{GC})$, the species were arranged into four groups: (a) about $55 \% \mathrm{GC}$, Trichosporon aculeatum, $T$. aquatile, T. cutaneum, $T$. inkin and T. pullulans; $(b)$ about $64 \% \mathrm{GC}$, $T$. eriense, $T$. fermentans and T. infestans; $(c) 59 \% \mathrm{GC}, T$. capitatum and $(d)$ $45 \%$ GC, $T$. penicillatum.

For 25 strains of the genus, $8 \mathrm{I}$ characteristics were selected for inclusion in a numerical taxonomic analysis with the aid of a computer. The dendrogram of the similarity values arranged these strains into three major branches arising at the $66 \% S$ level. Branch I includes Trichosporon aculeatum, T. cutaneum, T. infestans, $T$. inkin and T. pullulans. Branch II is limited to T. aquatile. Branch III includes $T$. capitatum, $T$. eriense, $T$. fermentans and $T$. penicillatum. Species arising from branch I at differing $S$ levels are T. aculeatum at $68 \% S, T$. pullulans at $72 \% S$, $T$. inkin at $75 \% S$ and $T$. infestans at $78 \% S$. The remaining strains in branch I belong to the $T$. cutaneum group.
\end{abstract}

\section{INTRODUCTION}

Determination of DNA base composition and the use of Adansonian analysis have been shown to be of considerable value in bacterial taxonomy (Marmur, Falkow \& Mandel, 1963; Sneath, 1964). Recently the application of these methods has been beneficial in studying the relationship among yeasts and other fungi. Storck (1966) determined the DNA base composition for I4 species of fungi representing I I genera; Stenderup \& Leth Bak (1968) did the same for I8 species of Candida. Nakase \& Komagata (1968) and Meyer \& Phaff (1969) reported the DNA base composition of yeast in several genera. Storck, Alexopoulos \& Phaff (1969) determined the DNA base composition for I 2 strains of the genus Cryptococcus, six strains of the genus Rhodotorula and 15 strains of the genus Sporobolomyces. Nucleic acid homologies were determined for species of Candida (Leth Bak \& Stenderup, 1969) and for species of Saccharomyces (Bicknell \& Douglas, 1970). KockováKratochvílová (1969) outlined the relationships for several species of Saccharomyces by applying Adansonian analysis.

The present paper deals with the DNA base composition of Io valid species belonging to the yeast genus Trichosporon and an Adansonian analysis of 25 strains of yeasts placed in this genus by various authors. The genus Trichosporon includes those yeasts in which sexual spores have not been found but which form both buds and arthrospores. The latter arise by the fragmentation of a mycelium and are arranged in a zigzag pattern. The members of this group have a variety of ecological origins and show wide ranges in the ability to use carbohydrates and L-amino acids as carbon sources (Hedrick \& Dupont, I968a). 


\section{METHODS}

Organisms used. The organisms studied (Table I) were either isolated by the authors from fresh waters (IIT, Illinois Institute of Technology strains) or were obtained from culture collections, including American Type Culture Collection (ATCC), Rockville, Maryland; Centraalbureau voor Schimmelcultures (CBS), Baarn, The Netherlands; Gulbenkian Institute of Science Culture Collection (IGC), Oeiras, Portugal; and Northern Regional Research Laboratories (NRRL), Peoria, Illinois. All cultures were reclassified according to the principles of Wickerham (I95I) and Lodder \& Kreger-van Rij (1952). Stock cultures were maintained and stored as slants on yeast extract-malt extract (YM) agar, which contained (g./1.): glucose, Io; peptone, 5; yeast extract, 3 ; malt extract, 3 ; and agar, 20. All strains were grown at $25^{\circ}$, except Trichosporon pullulans which was incubated at $10^{\circ}$.

\section{Table I. Trichosporon yeasts studied}

Name of yeast

T. aculeatum Phaff et Miller et Shifrine, I956

T. aquatile Hedrick \& Dupont, 1968

T. atlanticum Siepmann et Hohnk, 1962

T. behrendii Lodder et Kreger-van Rij, 1952

$T$. beigelii (Kuchenmeister et Rabenhorst) Vuillemin, I902

T. capitatum Diddens et Lodder, 1942

5 strains from fresh water

T. cutaneum (de Beurmann et Gougerot et Vaucher) Ota, I909

I4 strains from fresh water

T. cutaneum var. multisporum (Cochet, I940)

T. cutaneum var, peneaus Phaff et Mark et Williams, 1952

$T$. diddensii Phaff et Mark et Williams, 1952

T. eriense Hedrick et Dupont, 1968

T. fermentans Diddens et Lodder, 1942

T. giganteum Unna, I 896

$T$. hellenicum Vernona et Picci, 1958

$T$. infestans (Mosses et Vianna) Ciferri et Redaelli, I 913

T. inkin (Oho) do Carmo Sousa et Van Uden, 1967

T. loboi Batista et Campos et Oliveira, 1963

T. lodderi Phaff et Mark et Williams, 1952

T. margartiferum (Stautz) Buchwald, I93 I

T. maritimum Siepmann et Hohnk, 1962

T. penicillatum do Carmo Sousa, 1965

T. piscium Siepmann et Hohnk, 1962

T. pullulans (Lindner) Diddens et Lodder, 1942

T. sericeum (Stautz) Diddens et Lodder, I93I

T. undulatum Windisch, 1952
Culture collection no.

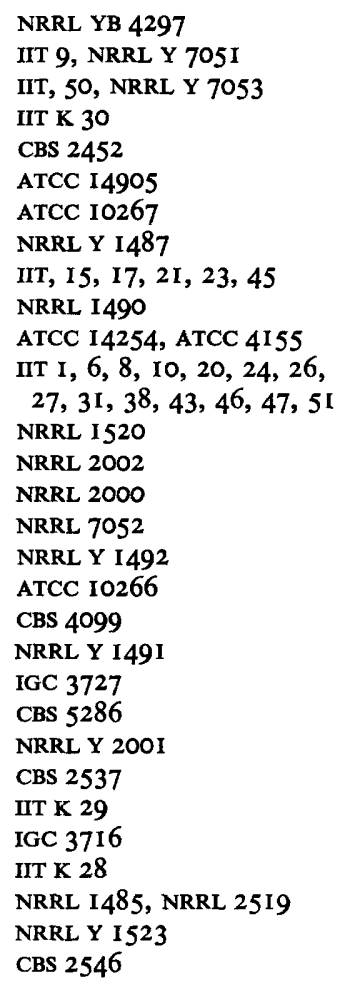

DNA extraction. The yeasts were grown for $24 \mathrm{~h}$. in YM broth and lyophilized; $30 \mathrm{~g}$. of dried yeast were suspended in $120 \mathrm{ml}$. of a solution of $0.15 \mathrm{M}-\mathrm{NaCl}+0 \cdot 1 \mathrm{M}-\mathrm{Na}$ ethylenediamine tetra-acetate $+2 \%$ sodium dodecyl sulphate $+\mathrm{I} \%$ mercaptoethanol at $\mathrm{pH} 8 \cdot 0$. The suspension was poured into a $\mathrm{I}$ l. beaker and exposed to chloroform vapours from a large cotton plug during incubation at $37^{\circ}$ for $24 \mathrm{~h}$. This treatment lysed enough of the yeast cells to release sufficient quantities of DNA for the base determination procedures for all organisms except Trichosporon aquatile and $T$. eriense. Eight alternate freezing and thawing 
treatments in liquid nitrogen altered the cells of these species for adequate lysis by the above method.

DNA purification. The DNA was concentrated and purified by the method of Marmur (196I), as modified by Meyer \& Phaff (1969). The DNA was precipitated by ethanol and collected by spooling the fibrous precipitate onto a glass rod.

Estimation of DNA base composition from absorbancy ratios. Fredericq, Oth \& Fontaine (196I) estimated the DNA base composition from the ratio of extinction values $\left(E_{280}: E_{280}\right)$ measured at $260 \mathrm{~nm}$. and at $280 \mathrm{~nm}$. De Ley (1967) compared the results obtained by this method with the thermal denaturation method of Marmur \& Doty (1962) and derived an empirical equation for an approximation of the \% guanine + cytosine ( $\%$ GC)

$$
\% \mathrm{GC}=\mathrm{I} 68 \cdot 6-87 \cdot 4\left(E_{260} / E_{280}\right) .
$$

For this method, the purified DNA was precipitated with isoamyl alcohol and redissolved in $5 \mathrm{ml} .0 .1 \mathrm{~N}$-acetic acid to give an extinction value of 0.3 to 0.5 at $260 \mathrm{~nm}$. when measured against $0.1 \mathrm{~N}$-acetic acid in a recording Beckman DB spectrophotometer. The \% GC was calculated from the above equation.

Determination of DNA base composition by thermal denaturation. Each sample of DNA was dissolved in $0.15 \mathrm{M}-\mathrm{NaCl}+0.15 \mathrm{M}-\mathrm{Na}$ citrate, $\mathrm{pH} 7$ (SSC) to give a solution containing approximately $20 \mu \mathrm{g}$. DNA $/ \mathrm{ml}$. according to the method of Burton (1956). The extinction of each sample was measured at $25^{\circ}$ at $260 \mathrm{~nm}$. against SSC; the temperature was then quickly raised to within $10^{\circ}$ of the estimated $T_{\mathrm{m}}$. The spectrophotometer was equipped with thermospacers heated at a constantly increasing rate by a circulating hot water bath containing ethylene glycol + water $(\mathrm{I}: 3)$. The rate of temperature increase was $0.2 \% \mathrm{~min}$. as monitored by a previously calibrated thermosensor immersed in the covered blank cuvette. The reliability of the method was checked by comparing the measured $T_{\mathrm{m}}$ value of Escherichia coli DNA with that given in the literature. The $T_{\mathrm{m}}$ values represent the midpoints of the extinction temperatures corrected for thermal expansion. The mean base composition (\% GC) was calculated from the equation of Marmur \& Doty (1962):

$$
\% \mathrm{GC}=\left(T_{\mathrm{m}}-69 \cdot 3\right) / 0 \cdot 4 \mathrm{I} .
$$

Numerical Taxonomy and Features. The numbers given to the features and the strains with their parameters as described by these features are summarized in the Appendix. The types of tests used are described below; the features number is given in parentheses. Each feature was coded for computer analysis according to the Adansonian principles of numerical taxonomy as developed by Sneath (1962). The primary aim was to group strains into clusters composed of related strains. The similarity index, $\% S$, was calculated using the following equation:

$$
\% S=n_{\mathrm{s}} \times 100 /\left(n_{\mathrm{s}}+n_{\mathrm{d}}\right),
$$

where $n_{\mathrm{s}}$ is the number of similar matches and $n_{\mathrm{d}}$ is the number of dissimilar matches. The program for the IBM $360 / 40$ computer was developed by the Computation Centre at Illinois Institute of Technology.

Over 100 features were determined for each of the 25 strains of Trichosporon but only 8I were incorporated into the data table as tests in which all strains gave $(+)$ or $(-)$ results were omitted. The latter included: (i) utilization tests - glucose $(+)$, ethanol $(+)$, inulin $(-)$, $8 \mathrm{~L}$-amino acids $(+)$ as a carbon source, and cysteine and cystine $(-)$ as a source of $\mathrm{C}$ and $\mathrm{N}$; and (ii) sensitivity to antimicrobial agents: nystatin $(+)$ and tributon chloride $(+)$.

Growth rate (features I to 3$)$. Extensive growth of the test organism in glucose $(0.5 \%, \mathrm{w} / \mathrm{v})$ 
in Difco yeast nitrogen base $(0.67 \%, w / v)$ (YNB) medium after incubation for 3 days (I), 7 days (2) or I4 days (3). If feature I was ( + ), features 2 and 3 were scored as 'no comparison' and indicated by $\left({ }^{*}\right)$. If feature 2 was $(+)$, feature 3 was scored as an $\left({ }^{*}\right)$.

Colony characteristics (features 4 to 9 ). These features were observed after 7 days incubation on the defined agar medium of Wickerham (1946). The characters recorded: (a) sheen shiny (4), intermediate between shiny and matt (5) or matt (6); (b) topography - smooth (7), intermediate between smooth and rough (8) or rough (9).

Pellicle formation (feature 10). Film formation after growth on glucose-YNB broth.

Growth at different temperatures (features II to I4). Good growth at $4^{\circ}$ (II), $15^{\circ}$ (I2), $25^{\circ}$ (13) and $37^{\circ}$ (14) was recorded.

Table 2. DNA base composition of valid species in the genus Trichosporon

\begin{tabular}{|c|c|c|}
\hline \multirow[b]{2}{*}{ Species } & \multicolumn{2}{|c|}{$\%$ GC } \\
\hline & From $E_{260} / E_{280}$ & From $T_{\mathrm{m}}{ }^{*}$ \\
\hline T. aculeatum NRRL YB 4297 & $54 \cdot 9$ & 55 \\
\hline T. aquatile NRRL Y 705I & $55 \cdot I$ & 55 \\
\hline T. capitatum NRRL Y 1487 & $60 \cdot 1$ & 59 \\
\hline T. cutaneum NRRL Y I 490 & $54 \cdot 5$ & 55 \\
\hline$T$. eriense NRRL 7052 & $62 \cdot 4$ & 64 \\
\hline T. fermentans NRRL Y I492 & $65 \cdot 0$ & 64 \\
\hline T. infestans NRRL I49I & 65.9 & 64 \\
\hline T. inkin IGC 3727 & $57 \cdot 6$ & 57 \\
\hline T. penicillatum IGC 37I 6 & $44 \cdot 9$ & 45 \\
\hline T. pullulans NRRL Y I485 & $56 \cdot 7$ & 55 \\
\hline
\end{tabular}

* $T_{\mathrm{m}}$ values represent averages of at least two determinations; the greatest difference between the two values was less than $I^{\circ}$.

Fermentation of glucose and galactose (features $\mathrm{I} 5$ to $\mathrm{I} 6$ ). The accumulation of $\mathrm{CO}_{2}$ within insert-tubes during growth in a medium containing $0.75 \%$ sugar $(\mathrm{w} / \mathrm{v})$ and $0.45 \%(\mathrm{w} / \mathrm{v})$ Difco yeast extract. Fermentative activities recorded were glucose (I5) and galactose (I6).

Carbohydrate ultilization (features 17 to 44 ). A positive result is the utilization of one of 29 carbohydrates after incubation for $2 \mathrm{I}$ days. Each carbohydrate solution was added to YNB to give a final carbohydrate concentration of $0.5 \%(\mathrm{w} / \mathrm{v})$. The carbohydrate and the YNB solutions were sterilized by filtration.

L-Amino acids utilized as nitrogen sources (features 45 to 55). The methods for media preparation and growth measurements were those of Hedrick \& Dupont (I968a).

L-Amino acids used as carbon and nitrogen sources (features 56 to $7 \mathrm{I}$ ). Media and methods were identical to those in preceding tests, except glucose was omitted.

Utilization of nitrate (feature 72). Two sets of agar media were inoculated with each yeast: one medium contained Difco yeast carbon base plus $0.78 \mathrm{~g} . \mathrm{KNO}_{3} / 1$. and $\mathrm{I} \cdot 5 \%$ Noble's washed agar (1928); the other medium contained no added nitrate. Equal growth on both media was scored as (-); greater growth on nitrate agar was recorded as $(+)$.

Splitting of arbutin (feature 73). Samples $(9 \mathrm{ml}$.) of arbutin $(0.5 \%, \mathrm{w} / \mathrm{v})$ containing Noble's agar ( $\mathrm{I} \cdot 5 \%$ ) were autoclaved, and after cooling to $50^{\circ} \mathrm{I} \mathrm{ml}$. of sterile YNB $(6.7 \%$, w/v) and $0.2 \mathrm{ml}$. of a saturated solution of $\mathrm{FeCl}_{3}$ (sterilized by filtration) were added. The formation of a dark purple-brown zone around yeast growth within 2I days was recorded as $(t)$ (Lodder \& Kreger-van Rij, 1952).

Sensitivity to antimicrobial agents (features 74 to $8 \mathrm{I}$ ). Yeasts grown for $24 \mathrm{~h}$. in glucose YNB broth were added to $10 \mathrm{ml}$. YM agar at $50^{\circ}$; this mixture was overlayered upon a base 
of Noble's agar $(1.5 \%)$ in a Petri dish. Paper discs containing different antimicrobial agents were placed upon the hardened overlay and incubated for $72 \mathrm{~h}$. Inhibition of growth around the discs was considered a $(+)$ test.

\section{RESULTS}

DNA base composition. As indicated in Table 2, the GC content in the DNA of five species is in the range of 55 to $57 \%$ and for four species it is in the range 59 to $64 \%$. Separated distinctly from these two groups is Trichosporon penicillatum with $45 \% \mathrm{GC}$ in the DNA. Although Nakase \& Komagata (I968) reported a $54 \%$ GC for $T$. pullulans and $59 \%$ GC for T. cutaneum DNA, we find a value of $55 \%$ for both species (based on the melting-point method). The different values from the two investigations for $T$. cutaneum could very well be due to strain differences in this heterogeneous species.

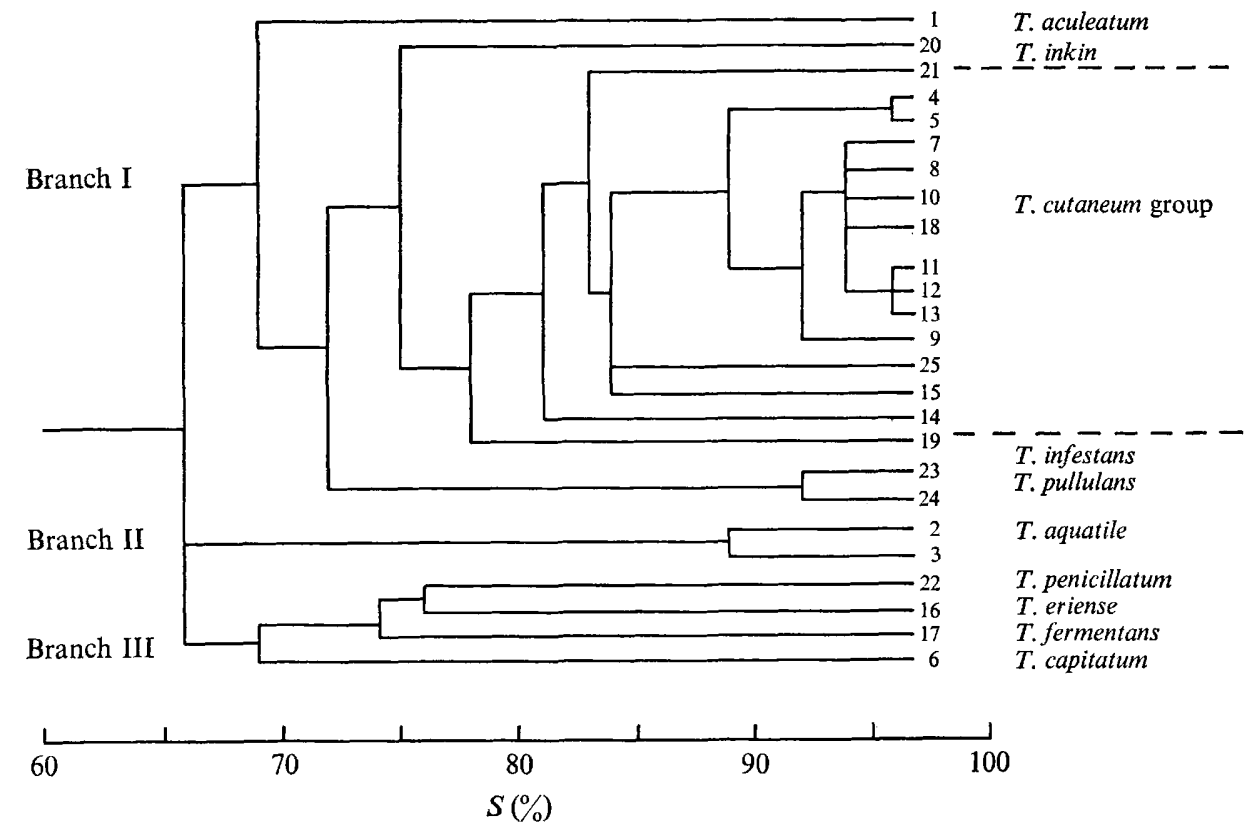

Fig. I. Dendrogram derived from computed $S$ values for 25 strains of Trichosporon yeasts. Numbers are those assigned to each strain in our laboratory.

Numerical taxonomy. The groupings obtained by using the $S$ values from the computed analysis of the taxonomic data are presented in the dendrogram (Fig. I). Three branches arise at the $66 \% S$ level. Branch I includes Trichosporon aculeatum, T. cutaneum, T. infestans, $T$. inkin and T. pullulans. Branch II is restricted to T. aquatile. Branch III includes T. capitatum, $T$. eriense, $T$. fermentans and $T$. penicillatum.

Species which split off from branch I at differing levels of similarity are Trichosporon aculeatum at $68 \% S, T$. pullulans at $72 \% S, T$. inkin $75 \% S$, and T. infestans at $78 \% S$. The remaining yeasts of this branch are those in the $T$. cutaneum group. The sorted similarity matrix table for all the strains, with the $S$ values shown as percentages, is given in Table 3 .

The differing characteristics of the yeasts in each branch are presented in the Appendix. 


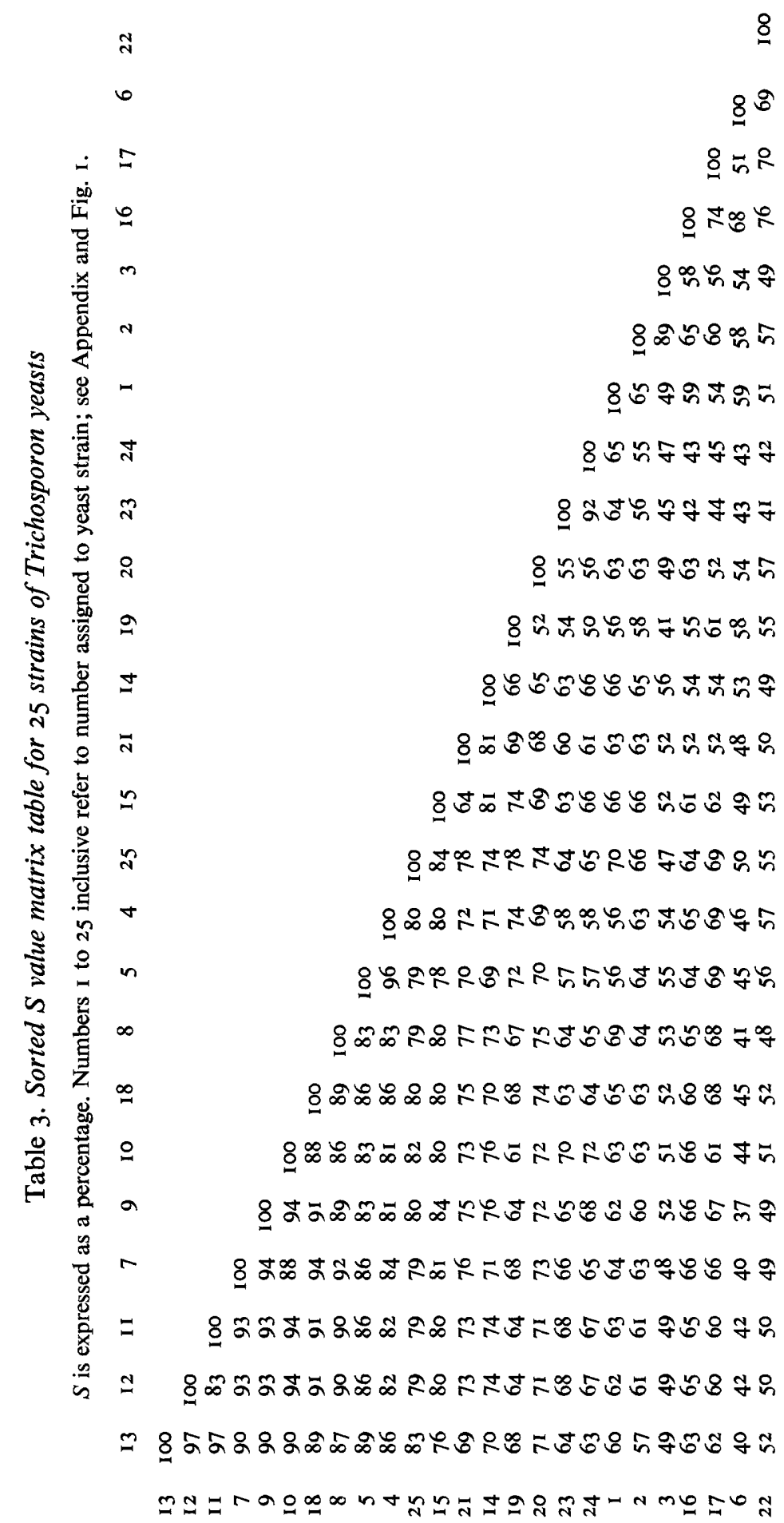


In summary: species in branch I (as a group) can use I4 more carbohydrates than can those in branch III; strains in branch II can use seven more carbohydrates than can those in branch III.

\section{DISCUSSION}

Forty-nine strains were studied and 40 were identified as valid Trichosporon yeasts. Trichosporon atlanticum, $T$. diddensii, $T$. hellenicum, $T$. lodderi, T. malassiezi, T. margaritiferum, $T$. maritimum and $T$. piscium produced neither arthrospores nor sexual spores, but did form a pseudomycelium. These characteristics are typical for members of the genus Candida. Trichosporon anglicum, $T$. behrendii and $T$. sericeum formed ascospores in addition to a true or false mycelium and therefore belong to the genus Endomycopsis. All other strains formed arthrospores, but none formed sexual spores when cultured on several different types of media known to induce spore formation; these yeasts are, therefore, valid strains of the genus Trichosporon. In addition to the I4 strains of $T$. cutaneum isolated from fresh water and three standard cultures obtained from culture collections, the following strains should be considered synonymous with $T$. cutaneum: $T$. beigelii, $T$. figueirae, $T$. giganteum, T. loboi and T. undulatum. This conclusion is in agreement with Carmo-Sousa (I970), out data from this and previous investigations disagree with her conclusion that $T$. infestans and $T$. cutaneum are synonymous. Hedrick \& Dupont (1968b) supplied evidence supporting their opinion that $T$. infestans should be maintained as a separate species. This decision is strengthened by the differences in the DNA base composition of these two organisms: T. cutaneum, $55 \% \mathrm{GC}$, and $T$. infestans, $64 \% \mathrm{GC}$.

The base composition of the DNA of a sufficient number of yeasts has been determined to warrant a brief comparison of this character for several genera. The 15 species studied by Meyer \& Phaff (1969), representing sporogenous yeasts or their corresponding imperfects, had GC contents of 34.9 to $48.3 \%$. These figures are representative of the lower range of values for the GC content of DNA, as are the values for 15 of 18 species of Candida (Stenderup \& Leth Bak, I968), where the average \% GC for the I8 species was 43.3 and the range was $35^{\circ}$ I to $57^{\circ} \%$ GC. Nakase \& Komagata (I968) reported the DNA base composition of 62 yeasts and yeast-like organisms; these included selected species of several genera. The \% GC in the sporogenous yeasts such as Endomycopsis, Saccharomyces, Pichia, and Hansenula ranged from 26 to $42 \cdot 5$. The ranges in \% GC for some of the asporogenous yeasts were 34 to 52 for Torulopsis, 32 to 59 for Candida, 46 to 56 for Cryptococcus, and 47 to 64 for Rhodotorula. Storck et al. (1969) reported the \% GC content for the genera Cryptococcus, Rhodotorula, and Sporobolomyces. For Cryptococcus the average was $55 \cdot 7$ (range $49^{\circ} 0$ to $65^{\circ}$ ), for Rhodotorula the average was $57^{\circ} 9$ (range $52^{\cdot 5}$ to $70 \cdot 0$ ), and for Sporobolomyces the average was $59^{\circ} 9$ (range $5 \mathrm{I} \cdot 5$ to $65^{\circ}$ ).

The DNA base composition for the asporogenous Trichosporon species are in the higher ranges of those reported for other yeasts. The general affinities of the Trichosporon species, based on the \% GC in the DNA, may be expressed as follows. Cluster A (about $55 \%$ GC): Trichosporon cutaneum, T. aculeatum, T. aquatile, T. inkin, and T. pullulans. Cluster B (about $64 \%$ GC): $T$. eriense, $T$. fermentans. Trichosporon capitatum is intermediate between these two groups with $59 \% \mathrm{GC}$, and $T$. penicillatum is distinctly different with $45 \% \mathrm{GC}$.

The sexual stages of Trichosporon yeasts have not been been elucidated; however, CarmoSousa (1969) found asexual endospores in Trichosporon capitatum, T. fermentans and T. cutaneum. Banno (1967) showed that Rhodotorula glutinis (DNA with $64 \%$ GC) has a life-history resembling the Ustilaginales of the basidiomycetes and established the genus Rhodosporidium for this species. Newell \& Fell (1970) and Newell \& Hunter (1970) have 
described similar life-histories for other Rhodotorula species; these also belong to the genus Rhodosporidium. Fell, Statzell, Hunter \& Phaff (1969) have shown that some species of Candida, including Candida scottii (DNA with $58 \cdot 5 \% \mathrm{GC}$ ), form teliospores which germinate into sporidia, and established a genus Leucosporidium to accommodate these species. Meyer \& Phaff (1970) predict that yeasts, whose DNA has about 50 to $70 \% \mathrm{GC}$, should have sexual stages similar to other yeasts in the ustilaginous group of fungi.

With certain exceptions, there was agreement in the taxonomic affinities of the Trichosporon species as determined by computer analysis and the DNA base composition results. Branch $I$ in the $S$ similarities dendrogram included Trichosporon cutaneum, $T$. aculeatum, $T$. inkin, $T$. pullulans and T. infestans. Cluster A of the base composition results included all branch I organisms except $T$. infestans, which has a distinctively higher $\% \mathrm{GC}$, and $T$. aquatile, which forms branch II of the dendrogram. The species in branch III of the $S$ dendrogram were $T$. eriense, $T$. fermentans, $T$. capitatum and $T$. penicillatum. Cluster B included the first two mentioned yeasts in branch III and T. infestans. The $\%$ GC for T. capitatum DNA is somewhat lower than that for the others in cluster B. The $\%$ GC for $T$. penicillatum is considerably lower and separates this organism from the other species in cluster B.

After the completion of this study two new species, Trichosporon fennicum (Sonck \& Yarrow, 1969), T. melibiosaceum (Scott \& van der Walt, 1970) and a new variety, T. cutaneum var. atlanticum (Goto, Sugiyama \& Iizuka, I969), have been described. These organisms were not included in this investigation.

This work was supported by the United States Public Health Service grant AI-04642 from the National Institute of Allergy and Infectious Diseases and National Science Foundation grants GY 695, GE 2376 and GY 4123.

\section{REFERENCES}

BANno, I. (1967). Studies on the sexuality of Rhodotorula. Journal of General and Applied Microbiology $\mathbf{1 3}$, I67-196.

Bicknell, J. N. \& Douglas, H. C. (1970). Nucleic acid homologies among species of Saccharomyces. Journal of Bacteriology xor, 505-512.

Burton, K. (1956). A study of the conditions and mechanism of the diphenylamine reaction for the colorimetric estimation of deoxyribonucleic acid. Biochemical Journal 62, 315-328.

Carmo-Sousa, L. Do (1969). In Proceedings of the Second International Symposium on Yeasts, Bratislava, Czechoslovakia, pp. 87-92.

Carmo-Sousa, L. Do (1970). Genus Trichosporon Behrend. In The Yeasts. Edited by J. Lodder. Amsterdam, The Netherlands: North Holland Publishing Co.

DELEY, J. (1967). The quick approximation of DNA base composition from absorbancy ratios. Antonie van Leeuwenhoek 33, 203-208.

Fell, J. W., Statzell, A. C., Hunter, I. L. \& Phaff, H. J. (1969). Leucosporidium gen. n., the heterobasidiomycetous stage of several yeasts of the genus Candida. Antonie van Leeuwenhoek 35, 433-462.

FredericQ, E., OTH, A. \& Fontaine, F. (I96I). The ultraviolet spectrum of deoxyribonucleic acids and their constituents. Journal of Molecular Biology 3, I I-17.

Goto, S., Sugtyama, J. \& Iizuka, H. (1969). A taxonomic study of Antarctic yeasts. Mycologia 6r, 748-774.

Hedrick, L. R. \& Dupont, P. (I968a). The utilization of L-amino acids as carbon source by yeasts of the genera Hansenula and Trichosporon. Antonie van Leeuwenhoek 34, 465-473.

Hedrick, L. R. \& Dupont, P. (1968b). Two new yeasts: Trichosporon aquatile and Trichosporon eriense spp. n. Antonie van Leeuwenhoek 34, 474-482.

KockovÁ-Kratochvílová, A. (1969). The taxometric study of the genus Saccharomyces. Antonie van Leeuwenhoek 35, Suppl. Yeast Symposium, A I5. 
Leth BAK, A. \& STENDerup, A. (1969). Deoxyribonucleic acid homology in yeasts. Genetic relatedness within the genus Candida. Journal of General Microbiology 59, 2 I-30.

Lodder, J. \& Kreger-van RiJ, N. J. W. (1952). The Yeasts. A Taxonomic Study. Amsterdam: North Holland Publishing Co.; New York: Interscience Publishers Inc.

MARMUR, J. (196I). A procedure for the isolation of deoxyribonucleic acid from micro-organisms. Journal of Molecular Biology 3, 208-2 I8.

Marmur, J. \& Doty, P. (1962). Determination of the base composition of deoxyribonucleic acid from its thermal denaturation temperature. Journal of Molecular Biology 5, 109-1 I 8.

Marmur, J., Falkow, S. \& Mandel, M. (1963). New approaches to bacterial taxonomy. Annual Review of Microbiology 17, 329-372.

MeYer, S. A. \& Phaff, H. J. (I969). Deoxyribonucleic acid base composition' in yeasts. Journal of Bacteriology 97, 52-56.

MeYer, S. A. \& Phaff, H. J. (1970). Taxonomic significance of the DNA base composition in yeasts. Spectrum, Recent Trends in Yeast Research, vol. I, pp. I-29. Edited by D. Ahearn. Atlanta, Georgia: Georgia State University.

Nakase, T. \& Komagata, K. (1968). Taxonomic significance of base composition of yeast DNA. Journal of General and Applied Microbiology I4, 345-357.

Newell, S. Y. \& FELL, J. W. (1970). The perfect form of a marine-occurring yeast of the genus Rhodotorula. Mycologia 62, 272-28I.

Newell, S. Y. \& HuNTER, I. L. (1970). Rhodosporidium diobovatum sp.n., the perfect form of an asporogenous yeast (Rhodotorula sp.). Journal of Bacteriology 104, 503-508.

Noble, R. E. (1928). A cyanide citrate pour plate medium for direct determination of the colon-aerogenes content of water and sewage. Journal of the American Water Works Association 19, I82-192.

ScotT, D. B. \& VAN DER WALT, J. P. (1970). Three new yeasts from South African insect sources. Antonie van Leeuwenhoek 36, 389-396.

SNEATH, P. H. A. (1962). The construction of taxonomic groups. Symposia of the Society for General Microbiology 12, 289-332.

SneAth, P. H. A. (1964). New approaches to bacterial taxonomy: Use of computers. Annual Review of Microbiology 18, 335-346.

Sonck, C. E. \& Yarrow, E. (1969). Two new yeast species isolated in Finland. Antonie van Leeuwenhoek 35, $172-177$.

Stenderup, A. \& Leth BaK, A. (1968). Deoxyribonucleic acid base composition of some species within the genus Candida. Journal of General Microbiology 52, $231-236$.

Storck, R. (1966). Nucleotide composition of nucleic acids of fungi. II. Deoxyribonucleic acids. Journal of Bacteriology 9r, 227-230.

Storck, R., Alexopoulous, C. J. \& Phaff, H. J. (1969). Nucleotide composition of deoxyribonucleic acid of some species of Cryptococcus, Rhodotorula and Sporobolomyces. Journal of Bacteriology 98, I0691072.

WiCKERHAM, L. J. (1946). A critical evaluation of the nitrogen assimilation tests commonly used in the classification of yeasts. Journal of Bacteriology 52, 293-30I.

Wickerham, L. J. (195I). Taxonomy of Yeasts. Technical Bulletin no. 1029. Washington, D. C.: U.S. Department of Agriculture. 


\section{APPENDIX}

Summary of the morphological and physiological characteristics of selected strains of Trichosporon yeasts

Each roman numeral: designation for a dendrogram branch. Each arabic numeral: designation for a yeast strain.

* No comparison

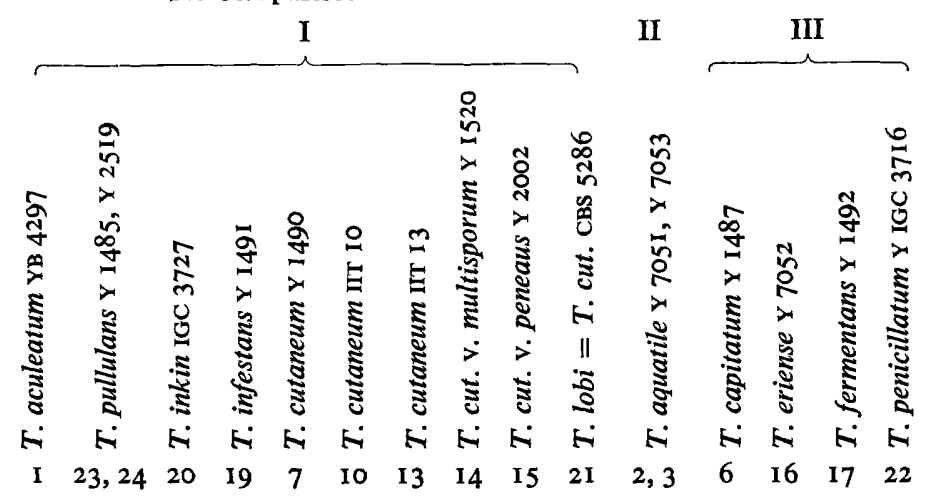

Features with their numbers

I $23,24 \quad 20 \quad 19 \quad 7 \quad 10$

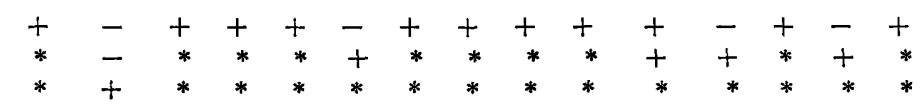

I. 3 days

2. 7 days

3. I4 days

Colony sheen and topography:

4. Shiny

5. Intermediate between shiny and matt

6. Matt

7. Smooth

8. Intermediate between smooth and rough

9. Rough

Miscellaneous features:

Io. Pellicle

II. Good growth at $4^{\circ}$

12. Good growth at $15^{\circ}$

13. Good growth at $25^{\circ}$

14. Good growth at $37^{\circ}$

I5. Glucose fermentation

$\begin{aligned} & - \\ & -\end{aligned}+-\overline{-}- \pm--\overline{-}-\overline{-}-\overline{-}$

I6. Galactose fermentation

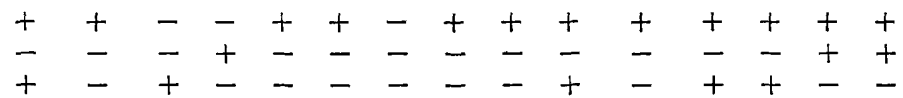

Use of carbohydrates as carbon source:

\begin{tabular}{|c|c|c|c|c|c|c|c|c|c|c|c|c|c|c|c|}
\hline 17. Galactose & - & + & + & + & + & $t$ & + & + & $t$ & + & + & + & + & + & + \\
\hline I 8. L-Sorbose & - & + & - & - & - & + & + & + & 一 & - & - & - & + & + & + \\
\hline I9. Sucrose & + & + & + & - & + & + & + & + & + & + & + & - & + & - & - \\
\hline 20. Maltose & + & + & + & + & + & + & + & + & + & + & + & - & - & - & - \\
\hline 2I. Cellobiose & + & + & + & + & + & + & + & + & + & + & + & - & + & + & 一 \\
\hline 22. Trehalose & + & + & + & - & + & + & + & + & + & + & + & - & - & - & - \\
\hline 23. Lactose & - & + & + & + & + & + & + & + & + & + &,+- & - & - & - & - \\
\hline 24. Melibiose & - & + & - & - & - & + & + & + & + & - & - & - & - & - & - \\
\hline 25. Raffinose & - & + & - & - & + & + & + & + & - & - & - & - & - & - & - \\
\hline 26. Melezitose & - & + & + & - & + & + & + & - & - & + & - & - & - & 一 & - \\
\hline 27. Soluble starch & + & + & + & - & - & 一 & - & + & - & - & + & - & 一 & - & - \\
\hline 28. D-Xylose & 一 &,+- & + & - & + & + & + & + & + & + & + & - & + & + & + \\
\hline 29. L-Arabinose & - & + & - & - & + & + & + & + & + & + & + & - & 一 & - & - \\
\hline 30. D-Ribose & - & 一 & + & + & + & + & + & + & + & + & + & - & - & - & - \\
\hline 31. L-Rhamnose & - & + & - & + & + & + & + & + & + & + & - & - & 一 & - & - \\
\hline 32. Glycerol & + & - & + & 一 & + & + & + & + & + & + & - & + & + & + & + \\
\hline 33. Erythritol & - & + & + & + & + & + & + & + & - & + & + & - & - & - & - \\
\hline 34. Ribitol & + & - & - & + & + & + & + & + & + & - & 一 & - & + & + & - \\
\hline 35. Galactitol & - & 一 & - & + & + & + & + & - & - & + & - & - & - & - & - \\
\hline
\end{tabular}


APPENDIX (cont.)

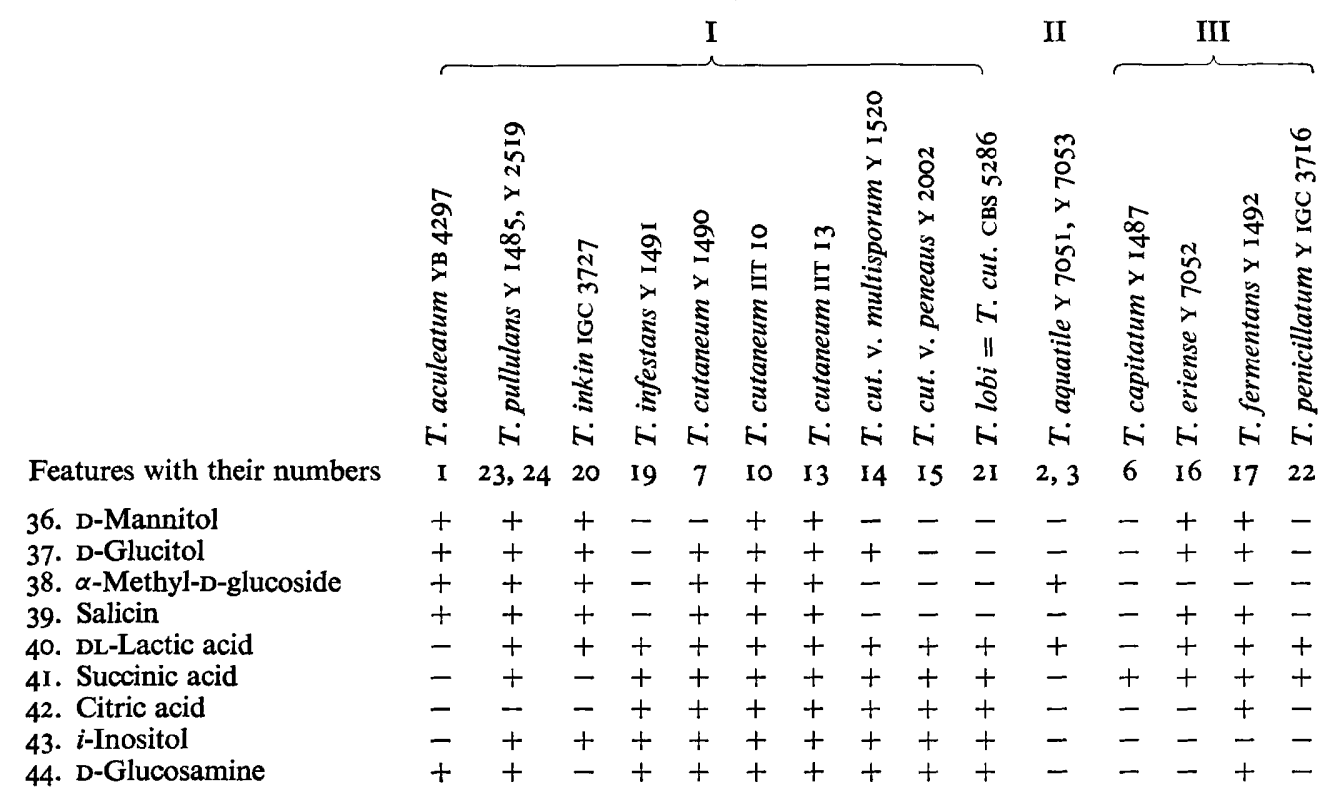

Use of L-amino acids as nitrogen source:
45. Aspartic acid
46. Cysteine
47. Cystine
48. Glycine
49. Histidine
50. Lysine
5I. Methionine
52. Phenylalanine
53. Serine
54. Threonine
55. Tryptophan

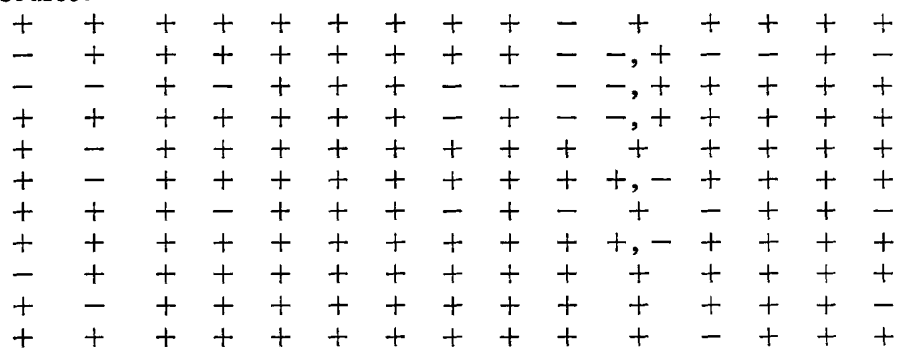

Use of L-amino acids as nitrogen and carbon source:

56. Alanine

57. Arginine

58. Aspartic acid

59. Glutamic acid

60. Glycine

61. Histidine

62. Isoleucine

63. Leucine

64. Lysine

65. Phenylalanine

66. Proline

67. Serine

68. Threonine

69. Tryptophan

70. Tryosine

71. Valine

72. Use of $\mathrm{KNO}_{3}$ as $\mathrm{N}$

73. Splitting of arbutin

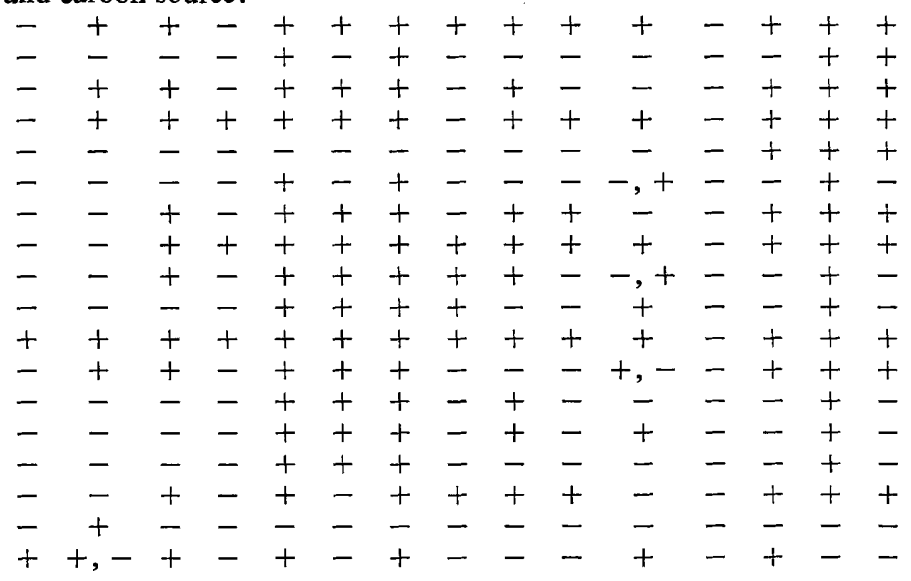

Sensitivity to antimicrobial agents:

\begin{tabular}{|c|c|c|c|c|c|c|c|c|c|c|c|c|c|c|}
\hline 74. Gantrisin & - & - & + & - & - & - & - & - & - & - & - & + & + & + \\
\hline 75. Elkosin & - & - & - & - & - & - & - & - & - & - & - & + & + & - \\
\hline 76. Madribon & - & - & - & - & - & - & - & - & - & - & - & + & + & - \\
\hline 77. Sulphadiazine & - & - & - & - & - & - & - & - & - & - & - & + & + & - \\
\hline 78. Sul-spansion & - & - & - & - & - & - & - & - & - & - & - & + & + & - \\
\hline . Mandelamine & - & - & - & - & + & - & - & - & + & - & - & - & - & - \\
\hline 80. Polymy & - &,+- & - & + & + & - & - & - & - & + & - & - & - & - \\
\hline 81. Sulphamerazine & - & - & + & - & - & - & - & - & - & - & - & - & ـ & - \\
\hline
\end{tabular}

